\title{
Limited Partnership
}

National Cancer Institute

\section{Source}

National Cancer Institute. Limited Partnership. NCI Thesaurus. Code C54137.

A business org anization with one or more general partners, who manage the business

and assume legal debts and obligations, and one or more limited partners, who are liable only to the extent of their investments. Limited partners also enjoy rights to the partnership's cash flow, but are not liable for company obligations. 